Дмитро Бучко

Тернопільський національний педагогічний університет імені Володимира Гнатюка

\title{
Спільне та відмінне у принципах номінації поселень і мікрооб'сктів
}

Вивчення лексико-семантичних і структурно-словотвірних особливостей ойконімії і мікротопонімії у слов'янській ономастиці уже має певні здобутки (про це свідчать бібліографії ономастичних праць Польщі, Чехії, Болгарії, України, Росії, Білорусії та ін.). Ми ставимо своїм завданням виявити спільне та відмінне у принципах номінації цих двох розрядів географічних назв.

Оскільки географічні об'єкти споконвіку оточували людей і виконували в їх житті виняткову роль, тому люди намагалися ідентифікувати, виділити окремі з них з-поміж ряду однорідних. Засобом виокремлення таких об'єктів серед інших стали саме власні назви. При називанні будь-якого об'єкта реальної дійсності власною назвою обов'язковими є три чинники: 1) номінатор, 2) об’єкт номінації, 3) засіб номінації (мовні одиниці: окремі слова чи словосполучення, за допомогою яких здійснюється називання реалії). Без мовного засвідчення оточуюча реальність залишається уявною, не пізнаваною до того часу, поки іiі складовим елементам не надано власних назв.

Важливе значення в процесі номінації географічних об'єктів власними назвами відіграють також наступні фактори: 1) потреба надавання конкретному об'єкту саме власної назви, 2) суспільно-економічні та політичні чинники, які сприяють чи перешкоджають такому процесу номінації. Безперечно, важливими є також соціальні умови, в яких відбувається називання конкретних об'єктів.

У вивченні особливостей називання відповідних географічних об'єктів власними назвами, встановленні критеріїв, принципів і способів їх номінації, передусім поселень, а також мікрооб'єктів, зроблено лише перші кроки. Вважаємо, що на сьогоднішній день недостатньо встановити, від чого і яким способом утворено той чи інший топонім (ойконім, гідронім, мікротопонім i ін.), а важливо встановити ще критерії, мотиви та принципи називання географічних об'єктів. 
Досліджуючи ойконімію різних регіонів України, ми зробили спробу встановити основні принципи, за якими здійснювалося називання поселень України в різні хронологічні періоди і виклали це у ряді наших статей [Бучко 2009: 41-51; Бучко 2010: 64-74]. Вважаємо, що при називанні поселень використовувалися чотири основні принципи номінації, кожен з яких реалізовувався через відповідні способи, мотиви та засоби називання. 1. Номінація поселення через відображення в його назві зв'язку з найменуванням окремої особи або з найменуванням групи осіб. 2. Номінація поселення через відображення в його назві зв'язку з назвами сусідніх географічних об'єктів. 3. Номінація поселення через відображення в його назві індивідуальних ознак самого населеного пункту. 4. Номінація поселення через відображення в його назві економічно-виробничих, суспільно-політичних факторів і пам'ятковості (називання поселень на честь відомих людей, подій і ін.).

Принципи номінації будь-яких об'єктів базуються на встановленні найвагоміших критеріїв, за якими реалізується називання. Це вираження відношення людини до об'єкта та характерні особливості самого об'єкта.

Вивчаючи ойконіми різних регіонів України, ми встановили, що найважливішим критерієм у процесі найменування поселень $є$ відношення назви конкретного населеного пункту до певної особи (найчастіше власника) або до групи людей, які заснували це поселення. Вагому роль у номінації населених пунктів відіграє також локалізація його у/на певній місцевості, зокрема наявність по сусідству інших, важливих для життєдіяльності людини об'єктів. Значно рідше мотивом номінації поселення служать характерні ознаки самого денотата.

Власними назвами на місцевості іменуються не тільки населені пункти, але й ряд інших, передусім незаселених об'єктів, які так чи інакше мають відношення до людини. Дотеперішні дослідження слов'янської мікротопонімії обмежувалися встановленням семантики етимонів мікротопонімів, виділенням структурно-словотвірних моделей назв мікрооб'єктів, визначенням способів їх деривації, а також простеженням лексичних, структурно-словотвірних і фонетичних змін цих назв на різних часових зрізах. Натомість принципи номінації незаселених територій поки-що залишалися поза увагою дослідників. Правда, польський учений Р.Мрузек виокремив 5 семантичних мотиваційних детермінантів, тобто мотивацій мікротопонімів: 1) топографічну, 2) культурну, 3) посесивну, 4) метафоричну, 5) ситуативно-обставинну [Mrózek 1990: 135-146].

Постає питання: чи можна застосувати визначені нами принципи номінації населених пунктів до найменування незаселених територій - полів, лісів, урочищ тощо. У тріаді, яка визначає суть номінаційного процесу - (номінатор - об’єкт номінації - засоби номінації) - два фактори (перший і третій) є більшменш однаковими при називанні поселень і незаселених об'єктів. Номінатором в одному і другому випадку є людина (інколи - колектив чи група людей). 
Засобами номінації в одному і другому випадках є лексика переважно рідної мови, але зміст лексичних одиниць і способи та засоби їх застосування у процесі номінації мікрооб'єктів, як показують наші спостереження та висновки дослідників мікротопонімії різних регіонів України [Білінська 2012; Яніцька 2012], принципово відрізняються від змісту етимонів ойконімів та способів творення останніх. І різниця ця випливає, перш за все, через абсолютно різну суть самих об'єктів номінації - населений пункт і незаселений об'єкт. Якщо перший створено за безпосередньою участю людей, то в другому випадку об'єкт номінації створений природою і не залежить безпосередньо від людини. Саме цей фактор є основною причиною відмінностей у принципах іменування поселень і незаселених об'єктів.

Принципи називання поселень України реалізуються через конкретні способи номінації за допомогою відповідних мовних засобів. Яким чином використано сформульовані вище принципи номінації поселень розглянемо на матеріалі ойконімії Покуття - давнього регіону України, що займає південно-східну частину Івано-Франківської області.

На території сучасного Покуття існує 295 поселень. Назви цих поселень по-різному розподілилися за кожним з виділених принципів номінації.

Наскільки придатними/непридатними є ці принципи для номінації мікрооб'єктів, покажемо, порівнюючи ойконімію та мікротопонімію Покуття. Для визначення принципів номінації в ойконімії названого регіону використовуємо матеріали нашої книжки [Бучко 1990], а номінацію мікрооб’єктів характеризуємо на основі власних матеріалів (1240 одиниць) та висновків дослідження лексико-семантичних та структурно-словотвірних особливостей мікротопонімії цієї ж території Л. Білінської [Білінська 2012].

\section{1. Відображення в назві об'єкта імені особи чи наймення людей, які мають відношення до цього об'скта}

За цим принципом номінації на території Покуття виникли назви поселень, що виражають їх приналежність особам, наймення яких зафіксовані в основах цих ойконів на: *-jь $\left({ }^{*}\right.$-је): Белелуя (давн. Білолой), Вербіж

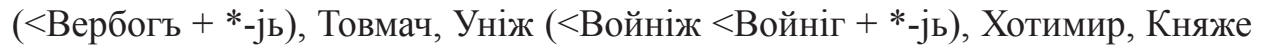
(усього 16 назв); -ів (<-ов), -ин: Борщів, Будилів, Гостів, Добротів, Жукотин, Молодятин (78 назв); -івка: Альбінівка, Ковалівка, Хом'яківка (28 назв). Приналежність виражають також ойконіми у формі Родового відмінка: Городенка, Турка (2 назви). Разом 124 ойконіми (42,03\%).

Перший принцип номінації презентують також ойконіми у формі множини: 1) відпатронімні (пол. nazwy patronimiczne) на -ичі, -івці, -инці: Добеславичі (суч. Добеславці), Корничі, Полагичі; Братківці, Вовківці, Іллінці, 
(29 назв); 2) відродинні (пол. nazwy rodowe) на -и/-і та ряд назв на -ани/-яни: Бортники, Годи, Тучапи; Драгомирчани, Берем'яни (27 назв); 3) утворені від локально-етнічних назв людей на -ани/-яни та від назв людей за місцем їх поселення стосовно примітних об'єктів: Добровляни, Озеряни, Тисменичани; Закрівці, Підгайчики (11 назв). Разом 67 (22,71\%) ойконімів у формі множини. За першим принципом номінації на території Покуття утворено 191 ойконім (64,74\%) названого регіону.

Розглянутий перший принцип номінації поселень спробуємо використати і для аналізу мікротопонімів. Головним способом його реалізації у мікротопонімії $є$ посесивність, а основними засобами вираження посесивності в українській топонімії здавна були суфікси -ів, -ин і їх варіанти, а також -к-а, -івк-а, -их-а, -(щ)ин-а та ін., а також форма Родов. відмінка однини.

Найчисельніше в мікротопонімії Покуття засвідчені назви на: -ів (-еве, -ове, -ова): п. Арсенчукова, П. Андрусево, п. Бадилеве, л. Батьків, ур. Бащікове, л. Будьків, п. Вахнюкове, ліс Гриськів, ур. Гушулкове та ін. (68 назв); а також складені форми мікротопонімів на зразок: ур. Анкілів Берег, ур. Барабашеві Вали, п. Безрукові Гори, пот. Берків Потік, ур. Ганякова Говда та ін. (44 назви); -ин (-ина, -ине): п. Бабин, п. Владичина, п. Костишине, ур. Микитине, ур. Микитчина, п. Сем'ятин (16 назв) і складені назви, напр.: ур. Бабин Кут, г. Барабашин Горб, ліс Гнатишині Дуби, п. Настасина Гора та ін.(18 назв). Приналежність в мікротопонімії часто виражає також суфікс -івк-а, напр.: п. Баличівка, п. Богунівка, п. Бранівка, п, Готарівка, пас. Осташівка і ін. (24 назви).

Значення посесивності в мікротопонімії може бути виражене ще іншими засобами, зокрема за допомогою суфіксів -к-а-, -их-а, -(ш)ин-а, -ець/-івець і форми Родов. відмінка: п. Баблянка, п. Балахтарка, ур. Остап’єнка, п. Петрунячка, п. Велика Атаманка (13 назв); г. Байцарівщина, п. Домніківщина, п. Титущина, п. Шляхотчина (6 назв); п. Бабчиха, п. Локотиха (2 назви); ур. Бутівець, п. Кобилець (2 назви); пас. Вахнюка, п. Криштафовича, п. Мироська, п. Трісколоза, ур. Хамливого, п. Воловського Лан (10 назв). На можливість суфікса -к-а виражати посесивність, здається, першим, ще в 40-их роках XX ст. звернув увагу польський мовознавець Зд. Штібер, і до них він зарахував ойконіми «Боднарка, тобто село Боднаря, Пельгримка, тобто село Пельгрима, сюди ж одночасно належать Блехнарка, Вавржка, а, може, також Перунка і Флоринка» [Stieber 1948: 71]. Разом за першим принципом номінації утворено 204 назви мікрооб'єктів (16.45\%).

Якщо за першим принципом номінації на території Покуття утворено $64,74 \%$ ойконімів, з яких 42,03\% зі значенням посесивності, вираженої в основному за допомогою суфіксів -ів, -ин, -івк-а, а також праслов'янського за походженням суфікса *-јь, то у мікротопонімії частка таких назв становить лише $16,45 \%$ від усіх аналізованих. Значення приналежності у них виражається в основному тими ж формантами, крім *-јь. Суттєвою різницею 
у вираженні посесивності в міротопонімії порівняно з ойконімію $є$ широке використання не тільки присвійних суфіксів -ів і -ин, але і їх родових варіантів -ев-е, -ов-е, -ов-а; -ин-а, -ин-е, а також суфіксів -к-а-, -их-а, -(щ)ин-а, -ець/-івець і форми Родов. відмінка.

За цим принципом не утворюються мікротопоніми у плюральній формі від назв людей, які в ойконімії (відпатронімні, відродинні та відлокально-етнічні назви) становлять $22,71 \%$. Наявні в мікротопонімії назви на зразок: Горбашівці, Нападневичі, Осташі виникли за іншим принципом номінації, про них скажемо пізніше.

\section{2. Відображення в назві іменованого об'скта назви сусіднього (рідко - віддаленого) географічного об'єкта}

За цим принципом творилися ойконіми від власних назв різних примітних об'єктів: 1) гідрооб'єктів: Білка (р. Білка), Велесниця (р. Велесниця), Вербовець (пот. Вербовець), Вільшаниия (р.Вільшаниця), Орелець (р.Орелець), Тисмениця, (р.Тисмениця), а ще Вікно, Саджава, Солотвина, Устя (33 назви); 2) топооб'єктів, які в минулому формували рельєфно-ландшафтні особливості обстежуваної території: Глинки, Долина, Кам'янки, Коломия, Кутище, Луг, Лука, Острівець, Росохач (12 назв); 3) фітонімооб'єктів: Виноград, Гвізд, Гвіздець, Діброва, Ліски, Хоросна, Ясінки, Старий Гвіздець (19 назв). За цим принципом, вважаємо, творилося й ойконіми на зразок: Загайпіль, Підвисоке, Підпечори; Забережжя, Загвіздя, Передівання, Підлужжя, Побережжя (11 назв). Разом за другим принципом номінації утворено лише 75 назв поселень $(25,42 \%)$.

Ойконіми розглянутих вище моделей, які формально є омонімними 3 апелятивами, утворено, за нашим переконанням, не безпосередньо від цих апелятивів, а від мікротопонімів. Адже поселення на зразок Вільшаниця, Долина, Кутище, Лука, Підлужжя і под. виникали біля/на тих місцевостях, які на час заснування тут населених пунктів уже мали свої власні назви, омонімні з назвами нововиниклих поселень. За цим принципом називання, імовірно, утворився й ойконім Товмачик (назва села недалеко м. Товмач, суч. Тлумач), хоча перенесення назви з одного об'єкта на інший й супроводжувалося деривацією.

За цим принципом номінації творилися також і назви незаселених об'єктів. У мікротопонімії Покуття цей принцип називання презентують:

1) мікротопоніми, утворені від назв примітних одиничних природних об'єктів: п. Баня (баня «соляне джерело»), п. Береза, п. Берда, п. Брідок, п. Бурдеї (бурдей «землянка»), п. Вапнярка, дол. Вікнина, п. Віха, п. Дубки, п. Кадуб, п. Могила, п. Осоки, п. Печери (32 назви); 
2) мікротопоніми, утворені від назв примітних одиничних, створених людиною об’єктів: ур. Брама, п. Броварищі, ур. Гумнищі, ур. Кошєри, п. Митнице, ур. Млин, п. Монастир, п. Пилорама (22 назви);

3) мікротопоніми, утворені від назв існуючих тут раніше населених пунктів, напр.: ур. Бгальці, п. Берестівці, п. Вернельки, ур. Галайки, п. Горбашівці, п. Жабокрики, ур. Клевчуки, л. Куськовиці, п. Мерлівці, луг Нападневичі, п. Пішаки, п. Стадники, ур. Тремби, п. Швайнери (51 назва).

4) мікротопоніми, утворені від назв об'єктів-орієнтирів, якими могли бути як назви відповідних місцевостей, так і іменування людей. Ці мікротопоніми мають таку структуру:

a) прийменник + назва об'єкта-орієнтира, виражена іменником або субстантивованим прикметником у непряму відмінку, напр.: Біля Бурової, В Бавках, В Грузькій, У Вилах, У Кливі, Від Горбасівки, Від Границі; До Мочила, До Прачки; За Валом, За Рудов, За Ставом; Коло Грушки, Коло Хреста; На Багні; На Білій, На Городищі; Під Вербами Під Горами, Під Мочіров та ін. (609 назв); б) прийменник + ім'я або прізвище власника оселі: Біля Тимка, До Марії, До Криставського, За Грешем, Коло Василька, Коло Андрусички, Коло Вовків, Коло Савковського, Коло Флійчука та ін. (24 назви); в) прийменник + назва об'єкта-орієнтира складеної структури: Коло Бабиного Хреста, Коло Сивого Плеса, На Горішній Поліні, На Двох Горбах, На Горах Коло Шкуратки, Над Білов Глинов, Над Куземковим Вивозом, Під Чорним Лісом, Під Янішовим Берігом, Ниви До Нішкович і ін. (30 назв); г) префіксальна назва мікрооб'єкта у Назив. відмінку однини чи множини, утворена від колишнього прийменникового сполучення, напр.: Заберезина, Заберестів, Загамарня, Закорчма, Замлаки, Міжводи, Міжозера, Межистави, Надвинниця, Надглибока, Переддолина, Підвисоке, Підгайки, Підлевада, Підмогилки (50 назв), д) назва мікрооб'єкта у конфіксальній формі: Задвір'я, Залісся, Залужжя, Запотіччя, Підлісся, Підпасіччя (9 назв). Разом за другим принципом номінації утворено 827 мікротопонімів (66,7\%).

Як бачимо, більшість (майже 2/3) аналізованих мікротопонімів Покуття утворено за другим принципом номінації, а в ойконімії частка назв, утворених за цим принципом, становить лише $25,42 \%$. Уже в цьому виявляється принципова різниця у номінації заселених і незаселених об'єктів. Суттєвою $\epsilon$ відмінність моделей ойконімів і мікротопонімів, утворених за цим принципом. Якщо ойконіми є результатом трансонімізації інших онімів (тобто поселення іменується власною назвою сусіднього об'єкта), то у творенні мікротопонімів переважає онімізація апелятивів та прийменникових конструкцій, тобто об'єкт іменують загальною назвою сусіднього об'єкта або шляхом визначення його розташування відносно іншого об'єкта за допомогою прийменника. Останній спосіб номінації (прийменникові конструкції) $\epsilon$ домінуючим у мікротопонімії Покуття (53,5\%). В ойконімії така модель номінації відсутня. 


\section{3. Відображення в назві об'єкта індивідуальних ознак самого об'єкта}

За цим принципом номінації утворилися лише окремі ойконіми Покуття: 1) які вказують на тип поселення, напр.: Городниця, Новосілка, Новоселиця, Княждвір, Монастир, Погоня (погоня «місце проживання замкових слуг, що розвозили пошту за наказом старости»), Сідлище (= селище), Слобода, Лісна Слобідка (13 назв); 2) у формі субстантивованих прикметників, які первісно були атрибутами у складених назвах, напр.: Глибока, Довге, Камінна, Красна, Лядське-Шляхетське (тепер Липівка), Надвірна, Надорожна, Назірна, Пасічна, Старуня (10 назв). Усього за третім принципом утворено лише 23 ойконіми $(7,79 \%)$ Покуття.

Натомість у мікротопонімії Покуття цей (третій) принципом номінації $€$ дуже продуктивним. Етимони мікротопонімів відображають:

1) рельєфно-ландшафтні ознаки місцевості: п. Балка, п. Берег, ур. Голиця, п. Гони, п. Додатки, пас. Долина, п. Зади, п. Контроверз, п. Лаз, п. Лани, пас. Луги, п. Луки, п. Облаз, п. Парцеляція, п. Ризи, п. Суходіл, п. Чорториї та ін.; п. Ближні Сіножаті, луг Великий Лан, п. Великі Рудки, п. Глибока Долина, п. Горішні Гони, п. Громадський Луг, п. Довгі Гони, ур. Зелений Лан, п. Перші Гони, п. Суха Рудка, п. Третій Кавалок, п. Чеський Лан (74 назви); 2) форму об'єкта: п. Квадра, п. Клин, п. Кривулі, п. Круглєк, п. Криве Поле, п. Кривий Лан (8 назв); 3) характер грунту: ур. Глинки, ур. Глинниця, п. Камнєнка, п. Камениски, пас. Рінь, п. Торфовиска, п. Біла Глина, ур. Велика Кам'янка (10 назв); 4) міра земельної площі: п. Морги, п. Півморги, п. Півшнури, п. Фальчі, п. Чверті, п. Шнури, п. Довгі Шнури (7 назв); 5) фітооб'єкти, рослинний покрив: л. Березина, л. Буковина, пас. Гаї, г. Гвізд, л. Діброва, л. Осичина, л. Чагор, ур. Черті, л. Трета Дуброва, ур. Чорний Ліс (23 назви); 6) гідрооб'єкти: пас. Багно, ур. Безденка, пас. Болото, пас. Млачки, ур. Мокрець, л. Мочір, дж. Орелець, дж. Суровиця, ур. Біла Криниця, оз. Чорне Озеро (18 назв); 7) орооб'єкти: ур. Вертеби, ур. Гріда, л. Діл, г. Клива, ур. Курган, л. Обіч, л. Сигла, г. Бита Гора, яр Білий Яр, г. Велика Говда, ур. Дві Могили, ур. Куций Горб, ур. Турецькі Могили (20 назв).

Індивідуальні ознаки мікрооб'єктів виражають також назви, що є субстантивованими прикметниками, які первісно були означеннями у складених назвах цих об'єктів. Мікротопоніми субстантивованої структури є двох типів: 1) субстантивований прикметник безпосередньо вказує на ознаку денотата мікротопоніма: г. Біла, ур. Глибоке, п. Гнила, п. Дике, п. Довга, п. Дубниче, п. Заднє, п. Каменисте, п. Криве, п. Крижувате, л. Нижній, ур. Прикре, л. Черлена, п. Чорне (22 назви); 2) субстантивований прикметник вказує на ознаку денотата мікротопоніма, виражену через назву сусіднього населеного пункту, напр.: п. Балинецьке, п. Думанське, п. Белелуйське, п. Бучаць- 
ке, п. Будилівське, п. Вербізьке, ур. Журацьке, п. Конопельне, ур. Троєцьке (17 назв).

До мікротопонімів, утворених за третім принципом номінації, ми зараховуємо ще назви, які виражають метафоричність, на зразок: пас. Близниці, п. Вила, л. Кобила, луг Лопата, п. Макітра, пас. Ріжок, пот. Золотий Потік, п. Молочний Горб (10 назв).

За третім принципом номінації, включаючи й метафоричні назви, утворено 209 мікротопонімів (16,85\% від усіх аналізованих).

Третій принцип номінації, за яким і ойконіми і мікротопоніми творяться переважно шляхом онімізації, має значну перевагу в мікротопонімії $(16,85 \%$ стосовно 7,79\% в ойконімії). Причиною цього є збереженням у назві мікрооб'єкта семантики його етимона.

\section{4. Відображення в назві об'скта результатів економічно- -виробничих, суспільно-політичних відносин, а також пам'ятковості}

На Покутті цей принцип номінації стосується лише назв поселень і презентується такими ойконімами: Майдан, Стебник (=омшаник «місце зберігання бджіл зимою»), Торговиця, Трач (=тартак), Середній Майдан, (5 назв). Гадаємо, що за четвертим принципом номінації утворилися й ойконіми Іспас i Троїця, які є результатом іменування населених пунктів за найменням церков, освячених у честь Спаса $=$ Спасителя (свято Преображення Господнього) і Св. Трійці (свято Зіслання Святого Духа). Разом за четвертим принципом номінації утворено 7 назв (2,67\%).

У проаналізованій нами мікротопонімії Покуття не виявлено назв, номінація яких відповідала б цьому принципові.

Порівнявши лексико-семантичну та словотвірну структуру ойконімів і мікротопонімів Покуття, вважаємо, що встановлені нами принципи номінації поселень доцільно використати і в дослідженні принципів номінації мікрооб'єктів, однак вони не можуть бути механічно перенесені в мікротопонімію.

При збереженні суті принципу номінації (1-й принцип: відображення в назві об'єкта імені особи чи наймення людей, які мають відношення до цього об'єкта; 2-й принцип: відображення в назві номінованого об'єкта назви сусіднього географічного об'єкта, 3-й принцип: відображення в назві номінованого об'єкта індивідуальних ознак самого об'єкта; 4-й принцип: відображення в назві об'єкта результатів економічно-виробничих, суспільно-політичних відносин, а також пам'ятковості) в ойконімії та мікротопонімії виявилися різні відносні показники: за першим принципом утворено 
64,74\% ойконімів і тільки 16,45\% мікротопонімів; за другим - 25,42\% ойконімів і аж 66,7\% мікротопонімів; за третім - 7,79\% ойконімів і 16,85 мікротопонімів; за четвертим - 2,67\% ойконімів, а в мікротопонімії аналогічних прикладів не знайдено.

Основною причиною відмінності у застосуванні принципів номінації в ойконімії та мікротопонімії є суттєва різниця між денотатами номінації. У першому випадку - це рукотворні об'єкти, які мають пряме відношення до людей, що їх населяють; у другому - це природні об'єкти, які мають лише дотичне відношення до людей. I тому засобами номінації для поселень служать переважно антропоніми та групові іменування людей, а для мікрооб'єктів - апелятиви (дуже часто топографічні терміни), які є орієнтирами для називання об'єктів, або їх назви стають власними назвами цих об'єктів

Суттєво відрізняються ойконіми та мікротопоніми і способами номінації. Для перших активно використовується трансонімізація, для других - онімізація. В структурному плані характерною особливістю ойконімії є велика кількість плюральних назв (в мікротопонімії їх значно менше), а характерною особливістю мікротопонімії є прийменникові конструкції (в ойконімії вони відсутні).

\section{Прийняті скорочення}

$$
\begin{array}{ll}
\text { г. } & \text { - гора } \\
\text { дж. } & - \text { джерело } \\
\text { л. } & - \text { ліс } \\
\text { п. } & - \text { поле } \\
\text { пас. } & - \text { пасовище } \\
\text { ур. } & - \text { урочище }
\end{array}
$$

\section{Бібліографія}

Білінська Любов Петрівна, 2012, Формування мікротопонімії Покуття, Івано-Франківськ. Бучко Дмитро, 1990, Походження назв населених пунктів Покуття, Львів.

Бучко Дмитро, 2009, Основні принципи і способи номінації поселень у Галицькій землі (за даними реєстру поселень з 1670 р.), „Українська мова” 4, 41-51.

Бучко Дмитро, 2010, Основні принципи та способи номінації поселень на території давнього заселення, [в:] Състояние и проблеми на българската ономастика, Велико Търново, 64-74.

Яніцька Наталія Романівна, 2012, Мікротопонімія центтральних та східних районів Львівської області, Львів.

Mrózek Robert, 1990, System mikrotoponimiczny Ślaska Cieszyńskiego XVIII wieku, Katowice.

Stieber Zdzisław, 1948, Toponomastyka Łemkowszczyzny, cz. I, Nazwy miejscowości, Łódź. 
Dmytro Buchko

\section{Common and different features in the naming principles of settlemnets and small geographic objects}

\section{(Summary)}

This work establishes commonnality in the naming principles of populated places (settlements) and other small geographic objects. Despite the different nature of settlements and other places and different methods of assigning proper names to different objects, there are some common nomination methods. In particular, these common methods include references to the fact that the object belongs to a specific owner or reflection of individual features of the object in its name.

Słowa kluczowe: nominacja, ojkonim, mikrotoponim, zasada nominacji.

Keywords: nomination, oikonym, microtoponym, nomination principles. 